\title{
Cannibalism in a small growth stage of the Early Permian branchiosaurid Apateon gracilis (Credner, 1881) from Saxony
}

\author{
Florian Witzmann \\ Museum für Naturkunde Berlin, Invalidenstraße 43, 10115 Berlin, Germany. \\ E-mail: florian.witzmann@museum.hu-berlin.de
}

\begin{abstract}
Received 8 May 2008

Accepted 31 July 2008

Published 20 February 2009

\section{Key Words}

amphibians

temnospondyls

gut content

An almost complete specimen of the branchiosaurid temnospondyl Apateon gracilis (Credner, 1881) with a skull length of approximately $7 \mathrm{~mm}$ from the Early Permian Döhlen Basin in Saxony is described that possesses a nearly complete conspecific specimen of approximately $4 \mathrm{~mm}$ skull length in its digestive tract. This is the first evidence of cannibalistic behaviour in small growth stages of branchiosaurids, whose dentition and hyobranchial morphology suggest adaptations to the capture of small invertebrates and feeding on small phyto- and zooplankton by filtering from the water. Therefore, cannibalism in small branchiosaurids certainly represents an exceptional case, possibly triggered by unfavourable environmental conditions.
\end{abstract}

larvae

Palaeozoic

Döhlen Basin

\section{Introduction}

Cannibalism has been observed in a variety of extant amphibians. In some species, cannibalism is a common phenomenon, whereas in others, it is an optional behaviour (Warburg et al. 1979; Crump et al. 1992; Degani 1993; Bressi et al. 1996; Thiesmeier 2004). Most frequently, amphibian eggs and larvae are subjected to cannibalistic predation, and most cannibals are found among larvae of urodelans and anurans. Superficially similar to extant urodelan larvae are the branchiosaurids, a group of temnospondyl amphibians that are known from Late Carboniferous to Permo-Triassic strata and reached an adult body size of $150 \mathrm{~mm}$. Branchiosaurids exhibit larval characters such as branchial dentition and external gills, and most of them are considered to be paedomorphic, water-dwelling animals (Bystrow 1939; Boy 1972; Boy \& Sues 2000). Their branchial denticles, attached to the mostly cartilaginous ceratobranchials, are often split distally into several tips and formed a fine trap in the gill region, suggesting that branchiosaurids relied on filter feeding of phytoand zooplankton at least to some extent (Boy 1993; Boy \& Sues 2000). However, large growth stages of branchiosaurids also fed on small vertebrates such as other branchiosaurid species or small fishes. Werneburg (1988a) reported large specimens of Melanerpeton eis- feldi (Werneburg, 1988) from Early Permian strata of the Thuringian Forest that preyed on small growth stages of Apateon kontheri (Werneburg, 1988), as indicated by gut contents. Rare cases of cannibalism have been reported in which small conspecifics have been discovered in the digestive tract of large branchiosaurids (Werneburg 1989). In the present study, I describe a small growth stage of the branchiosaurid Apateon gracilis from the Early Permian Döhlen Basin in Saxony with a smaller, nearly complete conspecific preserved in its digestive tract.

Werneburg (1991) revised Apateon gracilis and referred it to Melanerpeton gracile. A recent comprehensive phylogenetic analysis of branchiosaurids by Schoch \& Milner (2008), however, suggests the assignment of this species to the genus Apateon (see also a discussion of characters in Schoch \& Fröbisch 2006). Therefore, the binomen Apateon gracilis is preferred in the present study. Apateon gracilis is a medium-sized branchiosaurid that is represented by different growth stages ranging from 6 to $23 \mathrm{~mm}$ skull length, and is the only branchiosaurid species known so far of which metamorphosed, land-dwelling stages have been found (Werneburg 1991; Schoch \& Fröbisch 2006). Apart from Niederhäslich in the Döhlen Basin, Apateon gracilis has been demonstrated in the southwestern Saale Basin in Thuringia (Werneburg 1988b, 1991). The Niederhäslich de- 
positional setting is interpreted as a small, shallow lake with restricted inflow of freshwater (Boy 1977). Fishes have not been found in the lake sediments, whereas a rich tetrapod fauna has been reported. Apart from A. gracilis, the micromelerpetontid Branchierpeton amblystomus (Credner, 1881), the zatracheid Acanthostomatops vorax (Credner, 1883), the eryopid Onchiodon labyrinthicus Geinitz, 1861, as well as discosauriscids and microsaurs have been discovered (Boy 1977; Schneider 1994). The specimen described here is the first evidence of cannibalism of a small growth stage of a branchiosaurid and the first documentation of this behaviour in the Döhlen Basin.

\section{Material}

The specimen described here consists of an individual of Apateon gracilis (skull length approximately $7 \mathrm{~mm}$ ) from the lower limestone horizon of Niederhäslich near Dresden (Döhlen Basin; Asselian) with a smaller conspecific individual (skull length approximately $4 \mathrm{~mm}$ ) preserved as its gut content. It consists of slab and counterslab that are deposited in the Staatliches Museum für Mineralogie und Geologie Dresden, Saxony, under inventory number SaP 717. 1 and 2, labelled as 'Branchiosaurus gracilis'.

\section{Description of Apateon gracilis (Credner, 1881)}

The larger of the two specimens of Apateon gracilis (Credner, 1881) is represented by an almost complete skeleton including the anterior portion of the tail
(Figs 1,2). The skull is badly crushed so that individual bones cannot be discerned, and the marginal teeth are not preserved. The right stapes is visible at the posterior end of the skull table. Between skull and pectoral girdle, the branchial denticles are well preserved. Five rows of denticles are visible. As described by Werneburg (1991), individual denticles have a proximal globular base and several distal tips (up to four tips can be distinguished). The vertebral column, in which only the neural arches are ossified, is curved, and the short, straight ribs are visible only in the anterior three quarters of the trunk and in the anteriormost portion of the tail. In the posterior portion of the preserved part of the tail, ossified haemapophyses are visible. The pectoral girdle is poorly preserved, only the ill-defined outlines of one cleithrum and clavicle are visible, and the pelvic girdle is not preserved. Fore- and hindlimbs are present and almost complete.

A second, smaller specimen of A. gracilis is visible ventral to the vertebral column of the larger specimen, with its longitudinal axis aligned parallel to that of the larger specimen. Its fragmentary skull is located immediately posterior to the forelimbs of the large specimen. Individual bones of the skull can hardly be identified except for a portion of the dislocated premaxilla with three preserved teeth. The cleithrum is preserved posterior to the skull table. In the anterior trunk region, two rows of branchial denticles are present. The branchial denticles correspond in their morphology to - but are smaller than - those of the large specimen. From the presacral vertebral column, approximately 20 vertebrae are preserved. They continue to the presumed

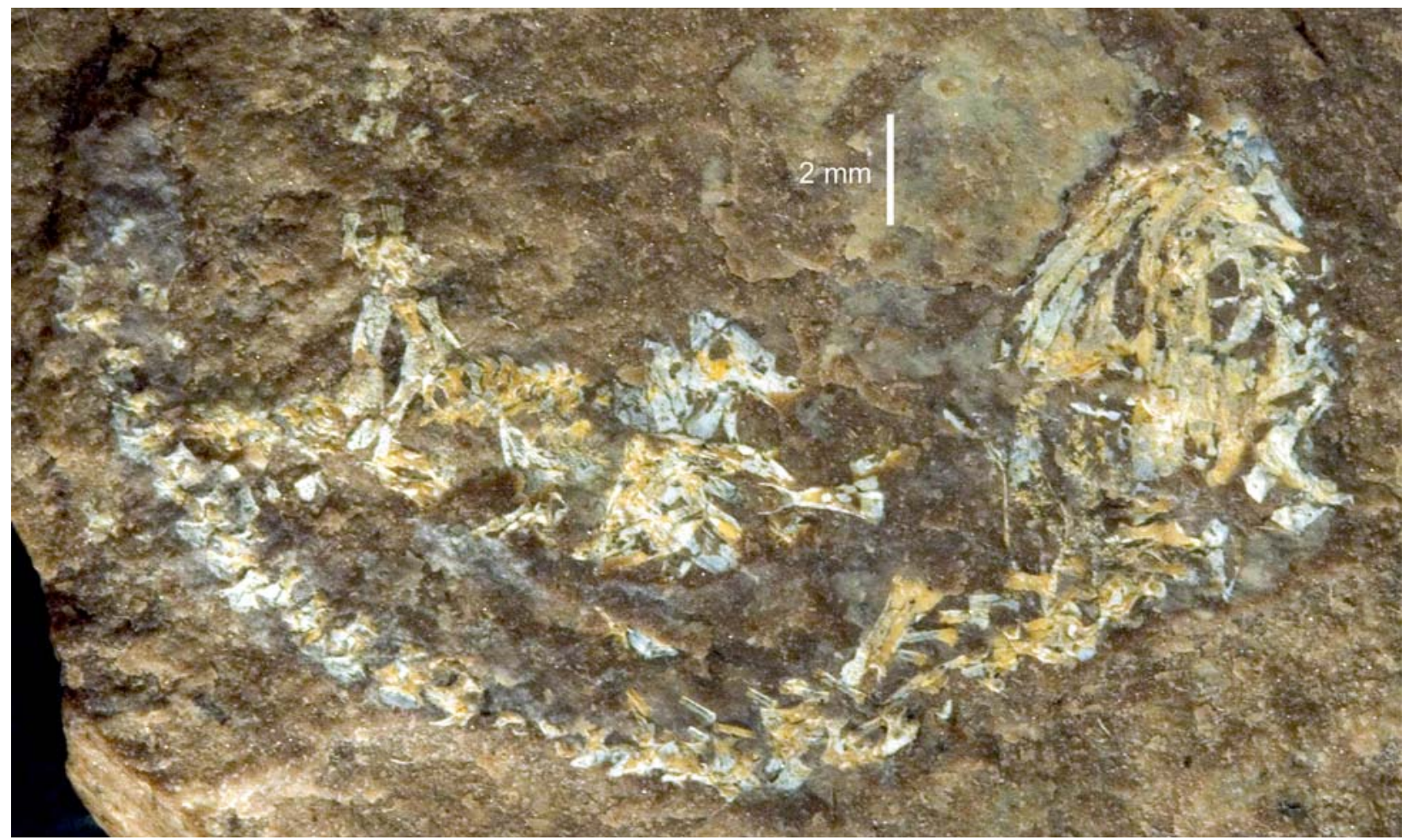

Figure 1. Photograph of Apateon gracilis (Credner, 1881) on slab MMG SaP 717.2. 


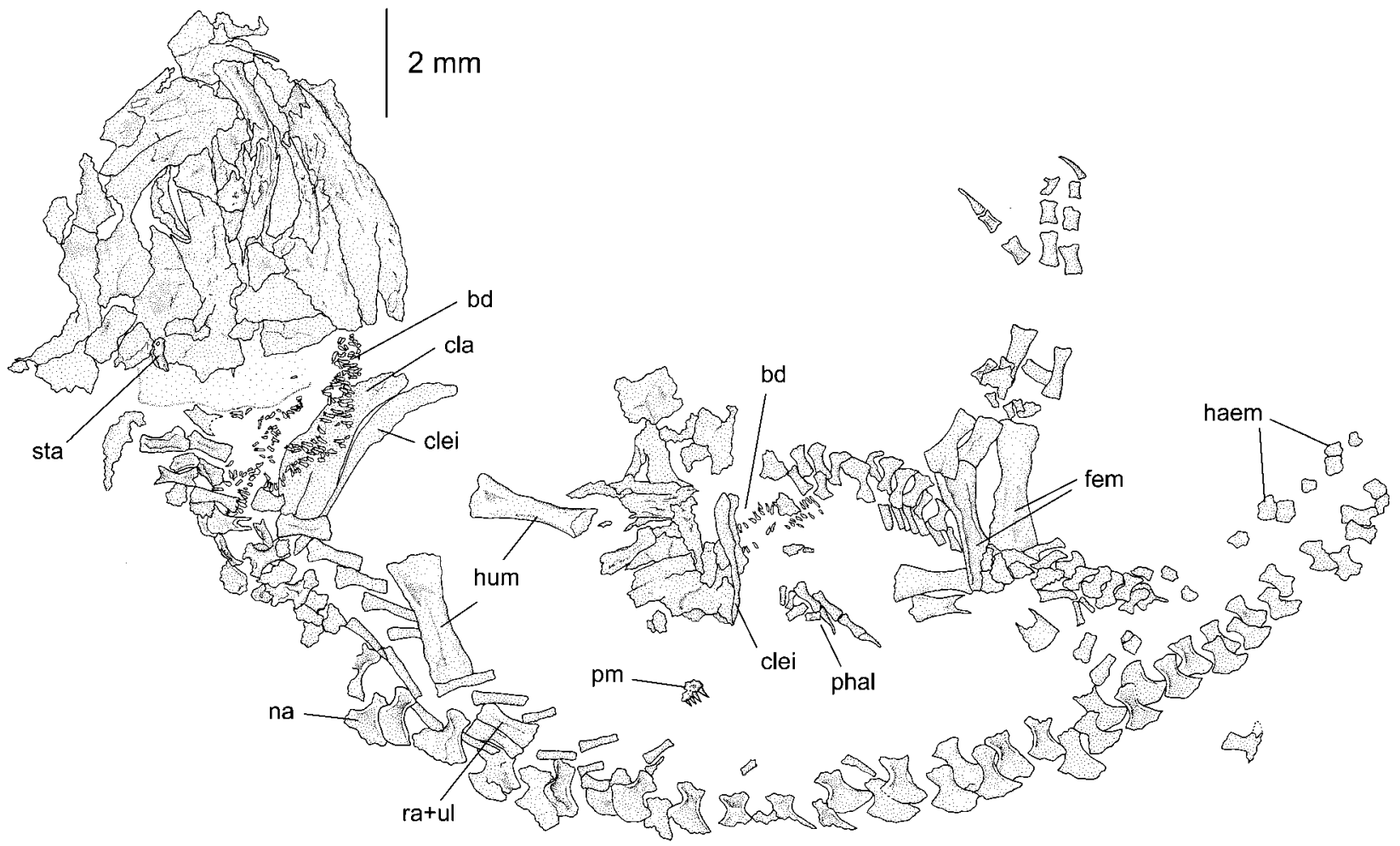

Figure 2. Drawing of the almost complete skeleton of Apateon gracilis (Credner, 1881) on slab MMG SaP 717.1 with a skeleton of a smaller conspecific preserved as prey item. Abbreviations: bd - branchial denticles; cla - clavicle; clei - cleithrum; haem haemapophyses; fem - femur; hum - humerus; na - neural arch; phal - phalanges; pm - premaxilla; $\mathbf{r}$ - rib; ra - radius; ul ulna.

cloacal region of the large specimen. Thereby, the column extends between the proximal parts of the femora of the large specimen (Fig. 3). Based on the proportions of the vertebral column, the neural arches, and the cleithra, one can estimate the size of the small specimen as

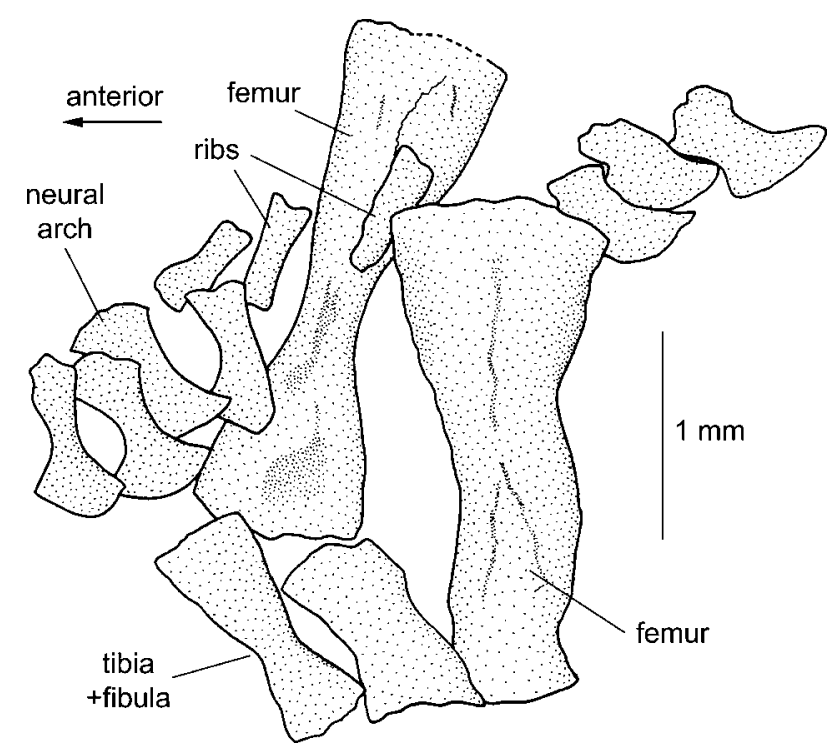

Figure 3. Drawing of the detail of counterplate $\mathrm{MMG} \mathrm{SaP}$ 717.2 showing that the vertebral column of the digested, smaller conspecific extended through the proximal portions of the femora of the larger specimen of Apateon gracilis (Credner, 1881). being $50-60 \%$ of that of the larger one, thus having a reconstructed skull length of approximately $4 \mathrm{~mm}$.

\section{Discussion}

Morphological features indicate that the two specimens are conspecific. The position of the smaller specimen relative to the larger one - specifically the fact that its backbone is ventral and parallel to the backbone of the larger specimen and situated between the femora of the latter - suggest that is was preyed upon by the larger specimen, and this testifies to the first record of cannibalistic behaviour in this branchiosaurid. In the stomachs of a sample of Salamandra salamandra (Linnaeus, 1758) larvae, the proportions of which are approximately comparable to those of branchiosaurids, Bressi et al. (1996) found conspecifics of about $40 \%$ of the size of the predators. However, larvae that measure more than half the size of their cannibalistic predators are also preyed on (Fig. 4; Thiesmeier 2004). As in this extant example of $S$. salamandra larvae, the cannibalistic $A$. gracilis attacked its smaller conspecific from behind and swallowed it tail first.

In branchiosaurids, direct evidence of cannibalism has been described by Werneburg (1989) in two large specimens of Melanerpeton sembachense Werneburg, 1989 with a skull length of $26 \mathrm{~mm}$ from the Early Permian of the Thuringian Forest, with small specimens of 


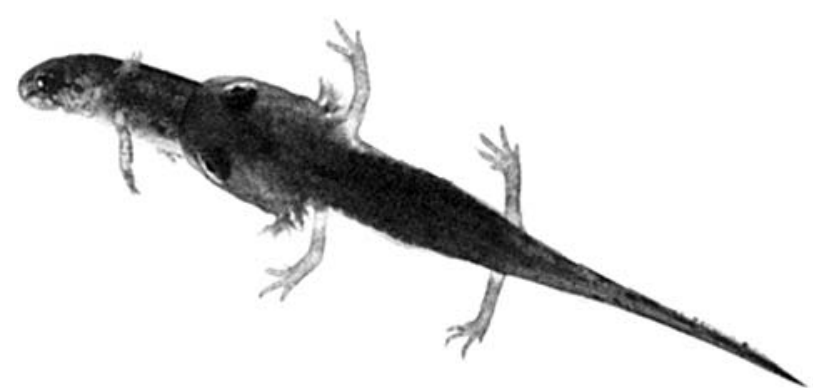

Figure 4. Cannibalism in larvae of the fire salamander, Salamandra salamandra (Linnaeus, 1758). The larger larva preys on a conspecific that measures more than half its size. Photograph used with kind permission of Burkhard Thiesmeier.

$9 \mathrm{~mm}$ skull length located just anterior to and within the mouth and in the trunk, respectively. Boy (1993) and Boy \& Sues (2000) reported Early Permian specimens of A.caducus (Ammon, 1889) from the SaarNahe Basin with skull lengths exceeding $12 \mathrm{~mm}$ that have branchiosaurid prey items preserved in their digestive tracts. It is, however, unclear if the gut remains can be assigned to the same species or to the smaller A. pedestris Meyer, 1844 (J. A. Boy, pers. comm. 2008). Each of these examples of cannibalistic branchiosaurids apply to specimens of large growth stages. In contrast, the cannibalistic A. gracilis reported here represents a small growth stage with a skull length of only $7 \mathrm{~mm}$. In small growth stages of branchiosaurids, no identifiable gut contents are generally preserved (Boy \& Sues 2000). Solely, Werneburg (1986) described a specimen of Apateon flagrifer (Whittard, 1930) from Friedrichroda (Thuringia) with a skull length of $10 \mathrm{~mm}$ that had preyed upon four small conchostracan crustaceans. As Boy (1993) and Boy \& Sues (2000) pointed out, branchiosaurids of small growth stages probably ingested very small prey items by filter-feeding, especially phyto- and zooplankton, which are, nevertheless not preserved. Additionally, small invertebrates from the lake bottom might have been captured.

The morphology of small growth stages of $A$. gracilis and other branchiosaurids of less than approximately $12 \mathrm{~mm}$ skull length indicate that they were not carnivorous: the small, slender and closely packed marginal teeth (Werneburg 1991) are not suitable for holding large, struggling prey; in addition, a tongue that could be used to facilitate transport of larger prey towards the oesophagus was almost certainly absent, as is the case in extant salamander larvae (Boy \& Sues 2000). Therefore, the capture of larger prey items like conspecifics and other vertebrates must have been rare exceptions for A. gracilis of the size class described here, since it must have been obviously very difficult and laborious to capture, fix and swallow this comparatively large prey. In extant anuran and urodelan larvae, cannibalism is obviously under partial genetic control, but triggered by environmental factors. This behaviour can be observed mostly in harsh environments like ephemeral water bodies that are overcrowded by conspecific am- phibian larvae, where other food resources are limited or absent (Crump 1992; Degani 1993; Bressi et al. 1996). Boy (1977) presumed that the Niederhäslich lake in the Döhlen Basin may have been temporarily reduced to residual water bodies, in which the aquatic tetrapods were crowded together. Similar to the situation in extant amphibian larvae, the high density of conspecifics and the presumable scarcity of food might have induced the cannibalistic behaviour in our example. However, because of the poor preservation of the skull, I cannot determine if the larger specimen had developed into a morph with enlarged teeth, a larger head, and a wider gape, as has been observed in some cannibalistic larvae of extant amphibians (Crump 1992).

\section{Acknowledgements}

I am grateful to Jürgen A. Boy, Andrew R. Milner and Rainer Schoch for helpful comments, and Ronald Winkler and Manuel Röthel (MMG Dresden) for the loan of the specimen. Robert L. Carroll, Nadia B. Fröbisch, and Marcello Ruta provided useful reviews. Burkhard Thiesmeier is gratefully thanked for the permission to use his photograph of S. salamandra larvae in Figure 4. Linda Tsuji kindly read the manuscript and improved the English grammar and style.

\section{References}

Ammon, L. von 1889. Die permischen Amphibien der Rheinpfalz. F. Straub, München.

Boy, J. A. 1972. Die Branchiosaurier (Amphibia) des saarpfälzischen Rotliegenden (Perm, SW-Deutschland). - Abhandlungen des hessischen Landesamtes für Bodenforschung 65: 1-137.

Boy, J. A. 1977. Typen und Genese jungpaläozoischer Tetrapoden-Lagerstätten. - Palaeontographica A 165: 111-167.

Boy, J. A. 1993. Synopsis of the tetrapods from the Rotliegend (Lower Permian) in the Saar-Nahe Basin (SW-Germany). In Heidtke, U. H. J. (ed.). New Research on Permo-Carboniferous faunas. Pollichia, Bad Dürkheim: pp. 155-169.

Boy, J. A. \& Sues, H.-D. 2000. Branchiosaurs: larvae, metamorphosis and heterochrony in temnospondyls and seymouriamorphs. In Heatwole, H. \& Carroll, R. L. (eds). Amphibian Biology, Volume 4, Palaeontology. Surrey Beatty \& Sons, Chipping Norton: pp. 1151-1197.

Bressi, N., Dolce, S. \& Stoch, F. 1996. Observations on the feeding of amphibians: IV. Larval diet of the fire salamander, Salamandra salamandra (Linnaeus, 1758), near Trieste (north-eastern Italy) (Amphibia, Caudata, Salamandridae). - Atti del Museo Civico di Storia Naturale di Trieste 47: 275-283.

Bystrow, A. P. 1939. Blutgefäßsystem der Labyrinthodonten (Gefäße des Kopfes). - Acta Zoologica Stockholm 1939: 125-155.

Credner, H. 1881a. Die Stegocephalen (Labyrinthodonten) aus dem Rotliegenden des Plauen'schen Grundes bei Dresden. Teil 1. Zeitschrift der deutschen geologischen Gesellschaft 33: 298-330.

Credner, H. 1881b. Die Stegocephalen (Labyrinthodonten) aus dem Rotliegenden des Plauen'schen Grundes bei Dresden. Teil 2. Zeitschrift der deutschen geologischen Gesellschaft 33: 574-603.

Crump, M. L. 1992. Cannibalism in amphibians. In Elgar, M. A. \& Crespi, B. J. (eds). Cannibalism. Ecology and evolution among diverse taxa. Oxford Science Publications, Oxford: pp. 256-276.

Degani, G. 1993. Cannibalism among Salamandra salamandra (L.) larvae. - Israel Journal of Zoology 39: 125-129. 
Geinitz, H. B. 1861. Dyas oder die Zechsteinformation und das Rotliegende, Teil 1: die animalischen Überreste der Dyas. W. Engelmann, Leipzig.

Linnaeus, C. von. 1758. Systema naturae per regna tria naturae, secundum classes, ordines, genera, species, cum characteribus, differentiis, synonymis, locis. Editio decima, reformata. Tomus I. Laurentii Salvii, Holmiae.

Meyer, H. von 1844. Briefliche Mitteilung an Professor Bronn. Neues Jahrbuch für Mineralogie 1844: 336-337.

Schneider, J. W. 1994. Environment, biotas and taphonomy of the Lower Permian lacustrine Niederhäslich limestone, Döhlen basin, Germany. - Transactions of the Royal Society of Edinburgh: Earth Sciences 84: 453-464.

Schoch, R. R. \& Fröbisch, N. 2006. Metamorphosis and neoteny: alternative developmental pathways in an extinct amphibian clade. - Evolution 60: 1467-1475.

Schoch, R. R. \& Milner, A. R. 2008. The intrarelationships and evolutionary history of the temnospondyl family Branchiosauridae. Journal of Systematic Palaeontology 6 (4): 409-431.

Thiesmeier, B. 2004. Der Feuersalamander. Laurenti Verlag, Bielefeld.

Warburg, M. R., Degani, G. \& Warburg, I. 1979. Growth and population structure of Salamandra salamandra (L.) larvae in different limnological conditions. - Hydrobiologia 64: 147-155.
Werneburg, R. 1986. Die Stegocephalen (Amphibia) der Goldlauterer Schichten (Unterrotliegendes, Perm) des Thüringer Waldes. Teil I: Apateon flagrifer (Whittard). - Freiberger Forschungshefte C 410: 88-101.

Werneburg, R. 1988a. Die Amphibienfauna der Oberhöfer Schichten (Unterrotliegendes, Unterperm) des Thüringer Waldes. - Veröffentlichungen Naturhistorisches Museum Schloss Bertholdsburg, Schleusingen 2: 3-27.

Werneburg, R. 1988b. Die Stegocephalen der Goldlauterer Schichten (Unterrotliegendes, Unterperm) des Thüringer Waldes. Teil II: Apateon kontheri n. sp., Melanerpeton eisfeldi n. sp. und andere. Freiberger Forschungshefte C 427: 7-29.

Werneburg, R. 1989. Die Amphibienfauna der Manebacher Schichten (Unterrotliegendes, Unterperm) des Thüringer Waldes. - Veröffentlichungen Naturhistorisches Museum Schloss Bertholdsburg, Schleusingen 4: 55-68.

Werneburg, R. 1991. Die Branchiosaurier aus dem Unterrotliegend des Döhlener Beckens bei Dresden. - Veröffentlichungen Naturhistorisches Museum Schloss Bertholdsburg, Schleusingen 6: 7599.

Whittard, W. F. 1930. The structure of Branchiosaurus flagrifer sp. n. and further notes on Branchiosaurus amblystomus Credner. - Annals and Magazine of Natural History 10: 500-513. 